\title{
Characterizing a piezotolerant catalase-producing Halomonas piezotolerans bacterium isolated from the New Britain Trench
}

\author{
FANGFANG YAN, ZHE XIE AND JIASONG FANG
}

Shanghai Ocean University

Presenting Author: m180200470@st.shou.edu.cn

Hydrogen peroxide $\left(\mathrm{H}_{2} \mathrm{O}_{2}\right)$ is widely used in paper, food, textile, and wastewater treatment industries as a bleaching or microbicidal agent. Usually, $\mathrm{H}_{2} \mathrm{O}_{2}$ used in these industries should be removed by catalase before further treatment. In this study, a piezotolerant Halomonas piezotolerans (strain $\mathrm{NBT} 6 \mathrm{E}^{\mathrm{T}}$ ) was isolated from deep-sea sediment of New Britain Trench at depth of $8900 \mathrm{~m}$. The strain was aerobic, motile, Gram-stain negative, rod-shaped, oxidase-positive and catalase-positive. Growth of the strain was observed at $4-45{ }^{\circ} \mathrm{C}$ (optimum, $30{ }^{\circ} \mathrm{C}$ ), at pH 5-11 (optimum, $\mathrm{pH} 8-9$ ) and in $0.5-21 \%(\mathrm{w} / \mathrm{v}) \mathrm{NaCl}$ (optimum, 3$7 \%$ ). The optimal pressure for growth was $0.1-30 \mathrm{MPa}$ with tolerance up to $60 \mathrm{MPa}$. Under optimal growth conditions, the strain could tolerate $15 \mathrm{mM} \mathrm{H}_{2} \mathrm{O}_{2}$. The purified catalase (KatE) was obtained by heterologous expression in Escherichia coli and Ni-NTA agarose gel column method. The enzymatic characteristics showed that the optimal substrate concentration was $60 \mathrm{mM}$, the optimal enzymatic activity temperature and $\mathrm{pH}$ were $20{ }^{\circ} \mathrm{C}$ and 7 , respectively. The optimal salinity was between $2-4 \%$. New findings on oxidative stress mechanisms of this strain will broaden our knowledge of stress adaptation of deep-sea bacteria and potentiate the biotechnological application of Halomonas species in the future. 